\title{
An Evaluation of Retail Brand Extension in the Context of Store Atmosphere, Perceived Quality of Parent and Extended Brands, and Perceived Fit
}

Beyza GÜLTEKIN (https://orcid.org/0000-0002-6797-864X), Department of Business Administration, Hacettepe University, Turkey; e-mail: beyza@hacettepe.edu.tr

Mehmet Kutlu SARAÇ (https://orcid.org/0000-0002-8283-8717), Department of Business Administration, Hacettepe University,Turkey; e-mail: kutlusarac@gmail.com

\section{Perakende Marka Genişlemesinin Mağaza Atmosferi, Ana Marka ve Genişletilmiş Markaların Algılanan Kalitesi ile Algılanan Uyum Çerçevesinde İncelenmesi}

\begin{abstract}
The purpose of this study is to examine the mediator role of the parent brand quality between the store atmosphere and extended brand quality and to investigate the moderator role of perceived fit in the effect of the parent brand quality on the extended brand quality. Data from 200 participants were collected through surveys conducted face-to-face in Ankara. The results of the process analyses reveal that the parent brand quality is a mediator between the store atmosphere and the extended brand quality. Perceived fit is a moderator between the parent brand quality and the extended brand quality.

Keywords

Store Atmosphere, Retailer Brand Extension, Parent Brand, Extended Brand, Perceived Fit, Perceived Quality.

JEL Classification Codes : $\quad$ M10, M19, M30, M31.

Öz

$\mathrm{Bu}$ çalışmanın amacı ana marka kalitesinin, mağaza atmosferi ve genişletilmiş marka kalitesi arasındaki aracılık rolünü incelemek ve ana marka kalitesinin genişletilmiş marka kalitesine etkisinde algılanan uyumun düzenleyicilik etkisini araştırmaktır. Veriler yüz yüze anket yöntemi ile Ankara'da yaşayan 200 katılımcıdan elde edilmiştir. Process analizi sonuçlarına göre, ana marka kalitesinin, mağaza atmosferi ve genişletilmiş marka kalitesi arasında aracılık rolü tespit edilmiştir. Ana marka kalitesinin genişletilmiş marka kalitesine etkisinde algılanan uyumun düzenleyicilik etkisi bulunmaktadır.
\end{abstract}

Anahtar Sözcükler : Mağaza Atmosferi, Perakendeci Marka Geniş̧lemesi, Ana Marka, Genişletilmiş Marka, Algılanan Uyum, Algılanan Kalite. 
Gültekin, B. \& M.K. Saraç (2021), “An Evaluation of Retail Brand Extension in the Context of Store Atmosphere, Perceived Quality of Parent and Extended Brands, and Perceived Fit", Sosyoekonomi, 29(48), 145-160.

\section{Introduction}

"An important component of a brand's value is tied to its contribution to launching new products" (DelVecchio \& Smith, 2005: 192). Introduction of a new product category within an existing brand name or as part of a brand extension is a preferred strategy for companies (Völckner \& Sattler, 2006). One of the most valuable elements in a company is its brand name (Klink \& Smith, 2001); thus, a commonly investigated area in the literature has been retail brand names (Alexander \& Colgate, 2005). In practice, retailers often use an existing brand name to perform a brand extension or when engaging in new retail operations. For instance, Tesco extended from supermarkets to banking services (Dwivedi \& Merrilees, 2013); Sears from department stores to financial services; Boots from drugstores to dental care (Alexander \& Colgate, 2005); and Zara from apparel to homeware retailing. Although numerous retailers have employed brand extensions and studies emphasized the importance of researches in retail-level branding (Barone, Norman \& Miyazaki, 2007), empirical studies on this topic have been scarce (Alexander \& Colgate, 2005; Laforet, 2007). Martinelli and Sparks (2003) conducted retailer extension research in the B2B context and found that consumer perceptions are important. Laforet (2007) identified that more researches are needed in the field of the non-food retailers' extension strategies. These studies highlight that understanding how consumers perceive retailers' brand extension strategies is significant.

In addition, brand extensions allow companies to reduce their launch investments in advertising and sales promotions (Völckner \& Sattler, 2006). The research by Ipsos and Medallia (based on 8.002 consumers in the USA, UK, Germany, and France) showed that the experience factor was more influential than advertising, the opinions of references, and brand reputations in consumers' decision to repatronize retailers (Madellia, 2018). In light of this finding, companies should pay more attention to the customer experience (Madellia, 2018). Store atmosphere, "the physical characteristics and surrounding[s] customers observe when interacting with any part of the retailer" (Stein \& Ramaseshan, 2016: 12), is a crucial aspect of marketing that enhances consumers' shopping experiences (Cho \& Lee, 2017).

Furthermore, retailers invest a considerable amount of resources to maintain and improve their store atmosphere. For example, 430 Tesco supermarkets were remodeled to create a warmer atmosphere after customers complained that the stores felt "cold and clinical" (Wood, 2012). Howland (2017) noted that Target expects to invest $\$ 1$ billion to overhaul its stores. Furthermore, McDonald's renovation investments for 8.700 of its restaurants are expected to reach $\$ 6$ billion by 2020 (Maynard, 2018). Besides investing in store atmosphere, fashion retail companies have also significantly invested in brand expansions in recent years (Dutzler, Kofler, Nitschke \& Kittel, 2016). Supposedly, however, many retail companies have not realized the expected returns on their investments (Dutzler et al., 2016). Based on this finding, store atmosphere should be further investigated to get a full sense of its impact on brand extension strategies. Surprisingly, however, store atmosphere has not been widely investigated in retail brand extension studies. One exception is the impact of the parent service brand's physical environment quality on the extension brand's quality (Völckner, Sattler, Hennig-Thurau \& Ringle, 2010). However, the potential 
role of parent brand and perceived fit is not considered in this relationship. The perceived fit, the level of categorical similarity to the parent brand (Ahluwalia, 2008) and/or the consistency of its items with those of the parent (Völckner et al., 2010), contributes to the success of companies' brand extension strategies (Gürhan-Canli, Sarıal-Abi, \& Hayran, 2018; Kim \& John, 2008), which are viable alternatives for retailers to add value, survive, and even grow in competitive environments (Alexander \& Colgate, 2005).

In extension studies, the parent brand quality and the perceived fit are thought to be the key determinants in the extension success (Milberg, Goodstein, Sinn, Cuneo \& Epstein, 2013). Perhaps, then, a better understanding of a store atmosphere's influence on the parent brands' perceived quality could help improve the outcomes of brand extension strategy. In the evaluation of extended brands, then, more investigation is needed in the areas of store atmosphere, the parent brand quality, and the perceived fit to help companies better understand how to succeed in their brand extension strategies. Therefore, this study contributes not only to the branding literature but also to the retailing literature by explaining the simultaneous relationships among the store atmosphere, the extended brand quality, the parent brand quality, and the perceived fit.

Against this backdrop, this study has two purposes. First, this study explores the impact of store atmosphere on the extended brand quality, as mediated by the parent brand quality. Second, this study examines whether the influence of the parent brand quality on the extended brand quality is moderated by the perceived fit.

\section{Conceptual Framework}

The model firstly, proposes that the parent brand quality acts as a mediator between the store atmosphere and the extended brand quality. Secondly, the effect of perceived quality of parent brand on the extended brand quality is moderated by the perceived fit. The model is shown in Figure 1. The related literature that supports the hypotheses is detailed in the following sections.

Figure: 1

Proposed Model

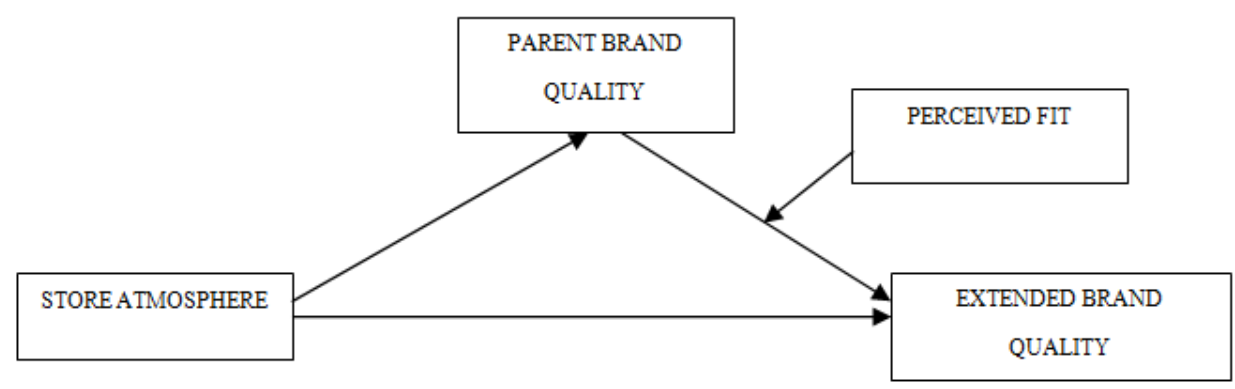


Gültekin, B. \& M.K. Saraç (2021), “An Evaluation of Retail Brand Extension in the Context of Store Atmosphere, Perceived Quality of Parent and Extended Brands, and Perceived Fit", Sosyoekonomi, 29(48), 145-160.

\subsection{Store Atmosphere - Extended Brand Quality: The Mediator Role of Parent Brand Quality}

Store atmosphere is regarded as the sensory effect comprising a store's design, physical features and exhibition activities (Cox \& Brittain, 2004). Ebster and Garaus (2015) maintained that the store atmosphere is created to influence consumers by appealing to their five senses. Therefore, store atmosphere serves as a customer-experience touchpoint (Stein \& Ramaseshan, 2016) and contributes to the customer experience (Verhoef et al., 2009). Customer experience may be more important than various aspects of a company-directed branding strategy, such as advertising to create service brand equity (Alexander \& Colgate, 2005). Meanwhile, perceived quality depends on consumers' subjective evaluations (Su, 2016) and is an abstract concept that can be difficult to comprehend (Garvin, 1984). However, only a few studies have explored the direct effect of store atmosphere on perceived quality. According to Gültekin and Özer (2012), store atmosphere influences the perceived quality of store brands. Liljander, Polsa, and van Riel (2009) found that positive perceptions of the atmosphere surrounding branded clothing items ensure a positive perception of quality. Völckner et al. (2010) discovered the impact of the parent brand's physical environment quality on the quality of the extended brand.

According to the cue theory, consumers can rely on a variety of cues to evaluate the product quality (Rao \& Monroe, 1988). Service design acts as a cue for quality by reducing consumers' negative emotions in service failures (Terres, Herter, Pinto \& Mazzon, 2020). In addition, store name is one of those quality cues (Rao \& Monroe, 1989). Furthermore, a store name is the "marquee" and is a part of the exterior store atmosphere (Berman \& Evans, 2013: 492). Meanwhile, the brand name is a quality cue which has a positive impact on perceived quality (Collins-Dodd \& Lindley, 2003; Richardson, Dick \& Jain, 1994). This suggests that the perceived quality of items that share the parent brand's name would be affected by the quality of the parent brand as well as by the store atmosphere.

Furthermore, based on the halo effect, if a variable is perceived positively, other variables associated with it might also be perceived positively (Thorndike, 1920). As a result of the halo effect, a positive perception of a store atmosphere might be related to the parent and extended brands quality. Extending this viewpoint, the parent brand quality might be affected by the store atmosphere and might in turn, influence the extended brand quality. As consumers' perception of a parent brand quality is high, their evaluations of the parent brand may be transferred to the extended brand much more easily (Keller \& Aaker, 1992; van Riel, Lemmink \& Ouwersloot, 2001).

Store atmosphere and the features of products are mentioned as two aspects of consumers' brand memory networks (Dwivedi \& Merrilees, 2013). This implies that when a person is to evaluate the quality of a brand this could activate or evoke other notes previously encountered such as parent brand store atmosphere and parent brand quality exposed in the previous experiences. Consequently, store atmosphere is connected to and can strengthen (weaken) consumers' brand-related evaluations, such as the quality of the parent and the extended brands. Accordingly, the following hypothesis is proposed: 
H1: Store atmosphere has a positive impact on the extended brand quality through the mediating role of the parent brand quality.

\subsection{Moderating Role of Perceived Fit}

Evidently, "researchers in different areas all agree that 'fit' is important-whether you are looking for a successful marriage, long-lasting friendship, or a great new product idea!" (Kim \& John, 2008: 125). The perceived fit relates to the degree of overlap or similarity of categories, images, benefits, and brand associations between the parent and extended brands (Ahluwalia, 2008; Broniarczyk \& Alba, 1994; Park, Milberg \& Lawson, 1991). Ahluwalia (2008) emphasized that in extension strategies, consistency in the categories of the parent brand (e.g., Harley Davidson footwear is in the product category of motorcycle apparel/accessories) and attributes (e.g., Godiva ice cream has attributes of richness and indulgence) are critical. Unless the product categories and attributes are similar in the parent and extended brands, the probability of success will be low, even when the target market (e.g., Lamborghini notebook computers) and the usage situation (e.g., Heinz cleaning vinegar) are consistent (Ahluwalia, 2008: 349). Therefore, perceived fit is a crucial element in an extension (Salinas \& Pérez, 2009: 50-60) and, when it is present, an extended brand may even strengthen the parent brand reputation (Chun, Park, Eisingerich \& MacInnis, 2015). For instance, with a high perceived fit in an extension, a parent brand having a weak reputation may be perceived as innovative (Chun et al., 2015). Perceived fit also directly affects brand value (Shao, Zhang \& Chen, 2015). It can impact consumers' attitudes directly and indirectly (Yang et al., 2013) such that, when perceived fit is high, uncertainty diminishes (Kim \& Yoon, 2013) and the brand extension strategy is viewed more positively by consumers (de Ruyter \& Wetzels, 2000). In contrast, as the perceived fit is low, both brands - parent and extended - can be negatively affected (Aaker \& Keller, 1990).

According to the theory of cognitive consistency, people want their thoughts and behaviours to be in agreement (Franzoi, 2009: 168). When people find that their attitudes and behaviours are conflicting, they are likely to change their emotions and attitudes or their behaviours (Gawronski \& Strack, 2004) to re-establish consistency. Thus, positive fit might strengthen the effect of the parent brand quality on that of the extended brand. In contrast, negative fit might weaken the effect of the parent brand quality on the extended brand.

Consistent with network theory, as consumers perceive that one brand is supporting another, as in brand extensions, a link forms between the two brand nodes (Vololato \& Unnava, 2006), and consumers perceive those brands as connected (Vololato \& Unnava, 2006). Exposure to an extended brand activates those brand nodes, and this activation can be stronger (weaker) because of the high (low) perceived fit between the two brands. The spreading effect increases as a result of the strength of the association between the two nodes (Balachander \& Ghose, 2003). Accordingly, when perceived fit is high, transferability of perceived quality is possible from parent to the extended brand or to a new product (Aaker \& Keller, 1990; Sunde \& Brodie, 1993). Bottomley and Doyle (1996) obtained similar results when measuring the generalizability of the model. The transferability of perceived fit (Aaker \& Keller, 1990) is important in terms of perceived quality and brand extension 
(Czellar, 2002). When consumers perceive a fit between the parent brand and the extended brand it becomes easier to transfer positive quality perceptions from one to another brand.

Extending this corollary, the second hypothesis is formulated:

H2. The effect of parent brand's perceived quality on the extended brand's perceived quality is moderated by perceived fit. The effect is stronger with high perceived fit and weaker with low perceived fit

\section{Methodology}

\subsection{Sampling}

The study data were collected from the customers of an internationally known retailer who recently implemented a brand extension strategy in Ankara, Turkey. The retailer operates in the ready-made (fast fashion) clothing sector, which had extended its operations to the homeware sector. Data were gathered with convenience sampling method via face-toface questionnaires in different regions (Cankaya, Etimesgut, Yenimahalle) of Ankara, capital city of Turkey. Questionnaire was administered to 200 individuals who confirmed their frequent visits to the retailer's apparel stores (the parent brand) and those have not been in the homeware retailer (extended brand). Sample size is sufficient by being more than 74 participants relying on the sample size formula $(\mathrm{N} \geq 50+8 \mathrm{~m}$; $\mathrm{N}$ : Sample Size; m: number of independent variables) of Tabanchnick \&Fidell (2013: 123). In this study, existing brands (as opposed to hypothetical ones) were utilized and data were collected from consumers, which enhanced external validity (Ramanathan \& Velayudhan, 2015: 778-801; Lei, Pruppers, Ouwersloot \& Lemmink, 2004: 243-255).

Respondents were between 18 and 68 years old, with an average age of 33 . In addition, most of the participants $(68.5 \%)$ identified themselves as being in the middleincome group; $66.5 \%$ of the sample had an undergraduate university degree; and majority of the respondents $(70 \%)$ were female.

\subsection{Measures}

Two marketing professors translated and backtranslated the scales for store atmosphere, the parent brand quality and the extended brand quality, and the perceived fit. The scales items were scored on a seven-point Likert scale, (1) for "strongly disagree" and (7) for "strongly agree.".

Store atmosphere: The scale used to measure the store atmosphere was measured with eleven items adapted from Chowdhury, Reardon \& Srivastava (1998: 72-86). Sample items are as follows: "The <store name> store is appealing," and "<Store name> is a nice place" (Chowdhury et al., 1998: 75).

Parent brand quality: Scale was adapted from Chowdhury et al. (1998: 72-86) has five items. Examples of items relating to the scale are as follows: "<Store name $>$ sells only 
high-quality products" and "I can count on the products I buy at <store name> being excellent” (Chowdhury et al., 1998: 74).

Extended brand quality: Extended brand quality was adapted from Sichtmann and Diamantopoulos (2013: 567-585) and included three items. Two examples are as follows: "The extension will be of superior quality" and "The quality of the extension will be good" (Sichtmann \& Diamantopoulos, 2013: 581).

Perceived fit: The perceived fit scale used in this study contained four items adapted from Sichtmann and Diamantopoulos (2013: 567-585). Examples are as follows: "[Extension] fits with the image of [brand] and "[Extension] is similar to other products offered by [brand]" (Sichtmann \& Diamantopoulos, 2013: 581).

\section{Analyses and Results}

Confirmatory factor analysis was performed by using AMOS to evaluate the psychometric properties of the scales (store atmosphere, the parent brand quality, the extended brand quality, and the perceived fit). The overall model revealed an acceptable fit ( $\chi 2$ df: 1.911; p< 0.001 RMSEA: 0.068; IFI: 0.959, CFI: 0.959, TLI: 0.951, RFI: 0.902, $\mathrm{NFI}=0.918$ ). Construct validity was measured through convergent and discriminant validity. Convergent validity was established through the confirmatory factor analysis results, as the factor loadings were higher than 0.50 (Bagozzi \& Yi, 1988), except that the loading of the first item in the store atmosphere scale was lower than 0.50 and excluded from further analyses.

The discriminant validity of the proposed model was supported by the correlation coefficients being lower than 0.90 (Kline, 2011: 116) and by the square root of the AVE values being greater than the correlation coefficients of the variables (Fornell \& Larcker, 1981: 39-50), as shown in Table 1.

Table: 1

\section{Descriptive Statistics}

\begin{tabular}{lccccccccccc}
\hline Variables & $\begin{array}{c}\text { Mean } \\
\text { (Std.Dev.) }\end{array}$ & Cronbach's Alpha & CR & AVE & Tolerance & VIF & 1 & 2 \\
\hline 1. Store Atmosphere & $5.22(1.29)$ & 0.95 & 0.95 & 0.69 & 0.411 & 2.43 & 0.830 & & \\
2. Parent Brand Quality & $4.87(1.30)$ & 0.91 & 0.90 & 0.66 & 0.395 & 2.53 & $0.734^{* *}$ & 0.813 & & \\
3. Perceived Fit & $5.05(1.28)$ & 0.89 & 0.90 & 0.71 & 0.479 & 2.09 & $0.664^{* *}$ & $0.680^{* *}$ & 0.84 \\
4. Perceived Quality of Extended Brand & $4.80(1.40)$ & 0.95 & 0.95 & 0.88 & & & $0.613^{* *}$ & $0.705^{* *}$ & $0.810^{* *}$ & 0.93 \\
\hline
\end{tabular}

Note: Square roots of AVE values of each scale are given italic in the diagonal axis

CR: Composite Reliability; AVE: Average Variance Extracted; VIF: Variable Inflation Factors $* * p<0.01$

The Cronbach's alpha values for store atmosphere, parent brand quality, extended brand quality, and perceived fit were higher than 0.70 and acceptable. The composite reliability values of the variables were acceptable, as they were higher than 0.70 (Fornell \& Larcker, 1981: 39-50). These values also demonstrate convergent validity (Fornell \& Larcker, 1981: 39-50). In addition, a multi-collinearity problem was not detected, as the variance inflation factors were lower than the threshold of 10 (Hair, Black, Babin \& 
Anderson, 2014: 200), and the tolerance value was above 0.1 (Midi, Sarkar \& Rana, 2010: 253-267).

Common method bias was not identified via common method variance (CMV) analysis (Podsakoff, MacKenzie, Lee \& Podsakoff, 2003: 879-903); including a latent CMV variable in the measurement model did not significantly progress the model fit $(\Delta \mathrm{CFI} / \Delta \mathrm{RMSEA}=0.052 / 0.23>0.01)($ Gentina \& Tang, 2018).

To test hypothesis H1, a simple mediator model (Model 4) of the process macro v3.3 (Hayes and Rockwood, 2017: 41) was conducted. Bootstrapping with a 95\% confidence interval (BootCI [0.299, 0.590]) with 5000 samples did not include zero (Hayes and Rockwood, 2017: 39-57), as shown in Table 2. This confirms the indirect effect of store atmosphere on the extended brand quality via the parent brand quality. Thus, H1 is supported.

Table: 2

Simple Mediation Model

\begin{tabular}{|c|c|c|c|c|}
\hline Effects & Coefficient & SE & $\mathrm{T}$ & $\mathrm{p}$ \\
\hline \multicolumn{5}{|l|}{ Direct Effect } \\
\hline (a) Store Atmosphere (X) $\rightarrow$ PBQ (M) & 0.742 & 0.048 & 15.207 & $0.000 * * *$ \\
\hline (b) $\mathrm{PQPB}(\mathrm{M}) \rightarrow \mathrm{EBQ}(\mathrm{Y})$ & 0.593 & 0.078 & 7.583 & $0.000 * * *$ \\
\hline (c) Store Atmosphere (X) $\rightarrow$ EBQ (Y) & 0.225 & 0.079 & 2.842 & $0.004 * *$ \\
\hline \multicolumn{5}{|l|}{ Total Effect } \\
\hline 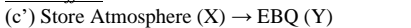 & 0.665 & 0.060 & 10.920 & $0.000^{* * *}$ \\
\hline Indirect Effect (Bootstrap) & Effect & Boot SE & Boot $95 \%$ & $\begin{array}{c}\text { Boot } 95 \% \\
\text { CI-UL }\end{array}$ \\
\hline Store Atmosphere $(\mathrm{X}) \rightarrow \mathrm{PBQ}(\mathrm{M}) \rightarrow \mathrm{EBQ}(\mathrm{Y})$ & 0.440 & 0.074 & 0.299 & 0.590 \\
\hline
\end{tabular}

$* * * p<0.001$

$* * p<0.01$

Perceived fit has a moderator role between the parent brand quality and extended brand quality by bootstrapping $(b=0.0567$, Boot \%95 CI $[0,0191,0.1014], \mathrm{t}=2.2612$, $\mathrm{p}<0.05$ ) with a $95 \%$ confidence interval with 5000 samples did not include zero (Hayes and Rockwood, 2017: 39-59) as given in Table 3. Therefore, H2 is supported.

Table: 3

Process Analysis Results for the Moderator Role of Perceived Fit: Parent Brand Quality-Extended Brand Quality

\begin{tabular}{|c|c|c|c|c|c|}
\hline \multirow[t]{2}{*}{ Paths } & Coefficient & Boot S.E. & $t$ & $P$ & $\begin{array}{l}\text { Boot \%95 Cl } \\
{[\text { Low, High] }}\end{array}$ \\
\hline & \multicolumn{5}{|c|}{$F(3,196)=158.4839, R=0.8415, R^{2}=0.7081 ; \Delta R^{2}=0.0076 p=0.000$} \\
\hline \multirow{2}{*}{$\begin{array}{l}\text { Constant } \\
\left(\mathrm{b}_{1}\right) \text { PBQ }(\mathrm{X}) \rightarrow \mathrm{EBQ}(\mathrm{Y})\end{array}$} & 4.7438 & 0.0681 & 77.6303 & $0.000^{* * *}$ & {$[4.6095,4.8798]$} \\
\hline & 0.3394 & 0.0755 & 5.8266 & $0.000 * * *$ & {$[0.1921,0.4850]$} \\
\hline$\left(b_{2}\right)$ Perceived Fit $(W) \rightarrow$ EBQ $(Y)$ & 0.6937 & 0.0704 & 11.8960 & $0.000 * * *$ & {$[0,5508,0.8268]$} \\
\hline$\left(\mathrm{b}_{3}\right) X * W \rightarrow \mathrm{EBQ}(\mathrm{Y})$ & 0.0567 & 0.0207 & 2.2612 & $0.0248^{*}$ & {$[0,0191,0.1014]$} \\
\hline
\end{tabular}

$* * * p<0.001$

$* p<0.05$

When perceived fit is low (-1.05), medium (-0.05), and high (1.45); the effect of parent brand quality on extended brand quality is investigated. When perceived fit is low, 
parent brand quality positively affects extended brand quality $(\mathrm{b}=0.2798, \% 95 \mathrm{CI}[0.1659$, $0.3937], \mathrm{t}=4.8454, \mathrm{p}<0.001)$. Similarly, when perceived fit is medium parent brand quality positively affects extended brand quality $(b=0.3366, \% 95 \mathrm{CI}[0.2223,0.4509], \mathrm{t}=5.8073$, $\mathrm{p}<0.001)$. As perceived fit is high, the relationship between parent brand quality and extended brand quality is significant $(\mathrm{b}=0.4712, \% 95 \mathrm{CI} 0,2721,0.5713 \mathrm{]}, \mathrm{t}=5.5583$, $\mathrm{p}<0.001)$.

Table: 4

Process Analysis Results for the Moderator Role of Perceived Fit: Low-Medium-High

\begin{tabular}{|c|c|c|c|c|c|}
\hline Paths & Effect & $S E$ & $t$ & $p$ & $\begin{array}{c}\% 95 \mathrm{CI} \\
\text { Low, High }\end{array}$ \\
\hline $\begin{array}{l}\text { PBQ }(\mathrm{X}) \rightarrow \mathrm{EBQ}(\mathrm{Y}) \\
\text { Perceived Fit }(\text { W): Low } \\
(-1 \text { Std. Dev. of the mean })\end{array}$ & 0.2798 & 0.0578 & 4.8454 & $0.0000 * * *$ & {$[0.1659,0.3937]$} \\
\hline $\begin{array}{l}\mathrm{PBQ}(\mathrm{X}) \rightarrow \mathrm{EBQ}(\mathrm{Y}) \\
\text { Perceived Fit }(\text { W): Medium } \\
(\text { The mean) }\end{array}$ & 0.3366 & 0.0580 & 5.8073 & $0.0000 * * *$ & {$[0.2223,0.4509]$} \\
\hline $\begin{array}{l}\mathrm{PBQ}(\mathrm{X}) \rightarrow \mathrm{EBQ}(\mathrm{Y}) \\
\text { Perceived Fit }(\text { W): High } \\
(+1 \text { Std. Dev. of the mean })\end{array}$ & 0.4712 & 0.0759 & 5.5583 & $0.0000 * * *$ & {$[0,2721,0.5713]$} \\
\hline
\end{tabular}
$* * * p<0.001$

Based on these findings and as shown in Figure 2, the impact of parent brand quality on extended brand quality is significant when perceived fit is low, medium and high. As perceived fit increases (decreases) the influence of parent brand quality on extended brand quality increases (decreases).

\section{Figure: 2}

\section{Moderator Role of Perceived Fit: Parent Brand Quality-Extended Brand Quality}

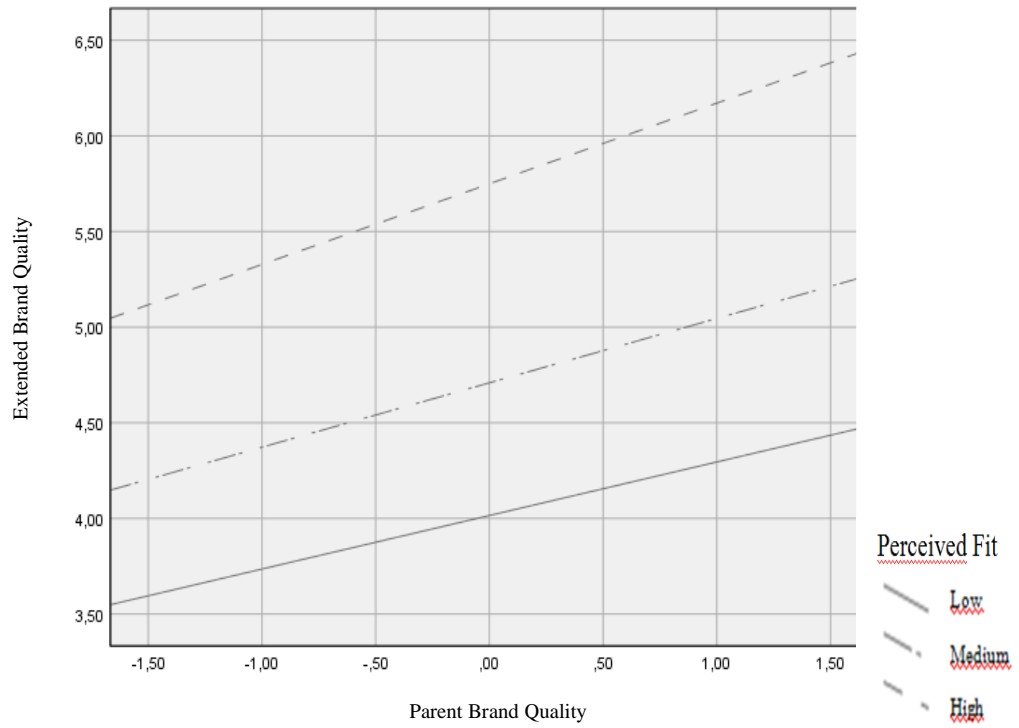


Gültekin, B. \& M.K. Saraç (2021), “An Evaluation of Retail Brand Extension in the Context of Store Atmosphere, Perceived Quality of Parent and Extended Brands, and Perceived Fit", Sosyoekonomi, 29(48), 145-160.

\section{Discussion, Conclusion and Managerial Implications}

The results reveal that the parent brand quality has a mediating role between the store atmosphere and the extended brand quality. Based on this finding, features such as the outlook, cleanliness, ambient temperature, and location of a store can all positively affect the extended brand quality via the parent brand quality. Furthermore, one might conclude that the investments in store atmosphere were transferred to the extended brand through the parent brand quality. This finding supports that the investments to the store atmosphere is not limited to the parent brand quality and/or in-store but to the out-of-store such as the extended brand quality.

Accordingly, the positive impact of atmosphere has on the extended brand is compatible with the cue theory, which explains the effect of the cues such as the brand name on perceived quality (Collins-Dodd \& Lindley, 2003: 345-352; Jacoby et al., 1971: 570579). Thus, when a retail store's name is used in a new (category) store, perceptions of the new products might have positively influenced by the parent brand's perceived quality. This result is also consistent with the findings of the service designs being a cue for perceived quality by suppressing negative emotions and increases behavioural intentions in service failures (Terres et al., 2020: 1-14). In addition, similar to the halo effect (Thorndike, 1920: 25), this study confirmed that when the store atmosphere is perceived positively, other variables associated with the store might also be perceived positively. In other words, when consumers evaluate an extended brand, they think about the quality of the parent brand, and these thoughts are enhanced by a pleasant store atmosphere.

Besides the perceived quality of the parent brand, the perceived fit is the other leading factor in the success of a brand extension strategy (Bottomley \& Doyle, 1996: 365-377). The results of this study revealed the moderator role of perceived fit between the parent brand quality and the extended brand quality. This outcome supports the theory of cognitive consistency, which posits that individuals strive for coherence in thoughts and behaviours (Franzoi, 2009: 168). Based on this theory, individuals are able to change the attitudes, behaviours, and emotions that are important to them (Gawronski \& Strack, 2004: 535-542). In addition, when the perceived fit between the parent and extension brands is high, parent brand associations and quality evaluations are more likely to be transferred to the brand extension (Gürhan-Canli et al., 2018: 96-117). This result is also consistent with the finding that as long as perceived fit is high, there is less risk in a consumer goods retailer investing in a brand extension involving consumer goods than in one that involves consumer services (Ramanathan \& Velayudhan, 2015: 797). This result also is in parallel to the network theory, which explains activation and spreading effects (Balachander \& Ghose, 2003: 4-13). These effects determine the strength of the related brand nodes in consumers' minds, which depend on previous exposure to the parent brand (Vololato \& Unnava, 2006: 196-202). By this way, the study also demonstrates the transferability feature of perceived fit (Aaker \& Keller, 1990: 27-41): the greater the fit between the parent and extended brands, the higher the level of parent brand quality that can be transferred to a new product (Echambadi et al., 2006: 253261). For example, a moderating role of a retailer-organic food fit is supported in the relationship between consumers' attitudes toward a retailer chain and consumers' choice of 
a retailer for organic food purchase (Hwang \& Chung, 2019: 293-306). In other words, a high perceived fit would result in the transfer of quality evaluations from the parent to the extended brand (Gürhan-Canli et al., 2018: 96-117). Similarly, consumers' exposure to a familiar brand evokes and activates previously encountered notes (Dwivedi \& Merrilees, 2013: 75-84) such as retailer store atmosphere and features of products.

In this study, the variable that most influenced the perceived quality of the extended brand was the perceived fit. It is obvious, then, that high/low perceived fit can be an advantage or a handicap in a brand extension. It follows that in their growth strategies, companies should first emphasize the perceived fit of the extension and related investments. In other words, investments should focus on ensuring that new brands are logical extensions of the parent brand and that there are similarities between the brands. Thus, efforts toward to achieve higher perceived fit would cause higher return of investment and greater success in the brand extension strategies in the retailing sector. Similar to Buil, de Chernatony, and Hem (2009: 1300-1324) suggestions, unless consumers perceive a high level of fit between the parent and extended brands, companies should use two brand names or introduce another brand name.

\section{Limitations and Recommendations for Further Studies}

The most frequently investigated factor in researches on brand extension strategies has been the perceived quality of the parent brand (Çifci \& Koçak, 2012: 105-118; O'Reilly et al., 2017; Völckner et al., 2010: 379-396). In the future, studies might examine the reciprocal effect of the perceived quality of the extended brand in brand and line extensions. Extended brand evaluations can also impact parent brand evaluations via spreadingactivation mechanisms (Dwivedi \& Merrilees, 2013: 75-84), and unsuccessful brand extensions could weaken parent brands, such as when IBM incurred a $\$ 15$ billion loss on personal computers as a result of their brand extension strategy (Laforet, 2007: 82-97). These events may result from a dilution effect or from the negative influence of inconsistent consumer attitudes towards a brand extension (Loken \& John, 1993: 71-84). Thus, the topic of how an extended brand influences a parent brand warrants further research.

Furthermore, companies who are able to reduce this perceived risk would be able to better exploit customers' quality associations in their brand extension strategies (Taylor \& Bearden, 2002: 131-140). Thus, this model might be extended by including the moderator role of perceived risk in the parent-extended brands perceived quality relationship.

A high-price strategy contributes more positively to product quality perceptions and customer product evaluations in dissimilar categories than in similar ones (Taylor \& Bearden, 2002: 131-140). In this framework, low and high prices might be included as moderators to test the impact of pricing on the perceived quality of products in retail brand extension strategies.

The characteristics of parent brands in terms of prestige versus functionality have been explored in the brand extension literature (Monga \& John, 2010: 80-92), whereas the characteristics of retailers have not been examined. In addition to prestige and functionality 
characteristics, high-end and low-end characteristics of retailers would serve as interesting subjects for further investigation.

In Turkey, almost all sales $(97.5 \%)$ of ready-made clothing and shoes were through store-based retailers, such as independent and chain retailers (Pricewaterhouse Coopers, 2016). Meanwhile, from April 2018 to March 2019, the percentage of consumers who shopped on the internet reached $34.1 \%$, with apparel and sports equipment as the most purchased items (67.2\%), followed by travel (31.7\%), food and daily needs (27.4), and homeware (26.9\%) (TUIK, 2019). Retailers with a high market share in e-commerce tend to offer a wider range of categories (Pricewaterhouse Coopers, 2016: 45). Therefore, in the future, researchers could also study this model in different retail sectors and channels, such as e-commerce.

In this study, the data were gathered from the customers of a global retailer. In the future, researchers could compare global companies to domestic companies engaging in brand extension strategies, or the model could be tested in other countries. Since culture also affects consumer perceptions of brand extensions (Buil et al., 2009: 1300-1324, GürhanCanli et al., 2018: 96-117) future studies could collect data from different countries and from individuals from diverse cultures to facilitate comparisons.

It has been found that the innovativeness of consumers inversely affects the influence of perceived fit on brand extension evaluations (Klink \& Smith, 2001: 326-335). Therefore, researchers might show how the trait of innovativeness affects evaluations of brand extensions in the retailing sector.

Moreover, Burt and Sparks (2002 cited in Alexander \& Colgate, 2005: 393-419) highlighted the importance of retailers building strong relationships with customers in their brand extension strategies. Therefore, this model could be extended by incorporating relationship-oriented concepts such as product satisfaction, store satisfaction, and store loyalty.

\section{References}

Aaker, D.A. \& K.L. Keller (1990), “Consumer Evaluations of Brand Extensions”, Journal of Marketing, 54(1), 27-41.

Ahluwalia, R. (2008), "How Far Can a Brand Stretch? Understanding the Role of Self-Construal", Journal of Marketing Research, XLV(June), 337-350.

Alexander, N. \& M. Colgate (2005), “Customers' Responses to Retail Brand Extensions”, Journal of Marketing Management, 21, 393-419.

Balachander, S. \& S. Ghose (2003), "Reciprocal Spillover Effects: A Strategic Benefit of Brand Extensions", Journal of Marketing, 67(January), 4-13.

Barone, M.J. \& A.T. Norman \& A.D. Miyazaki (2007), "Consumer response to retailer use of causerelated marketing: Is more fit better?”, Journal of Retailing, 83(4), 437-445.

Berman, B. \& J.R. Evans (2013), Retail Management: A Strategic Approach, Essex: Pearson Education Limited. 
Bottomley, P.A. \& J.R. Doyle (1996), “The formation of attitudes towards brand extensions: Testing and generalising Aaker and Keller's model", International Journal of Research in Marketing, 13(4), 365-377.

Broniarczyk, S.M. \& J.W. Alba (1994), "The Importance of the Brand in Brand Extension", Journal of Marketing Research, 31, 214-228.

Buil, I. \& L. de Chernatony \& L.E. Hem (2009), "Brand extension strategies: perceived fit, brand type, and culture influences", European Journal of Marketing, 43(11/12), 1300-1324.

Cho, J.Y. \& E.-J. Lee (2017), 'Impact of interior colors in retail store atmosphere on consumers' perceived store luxury, emotions, and preference", Clothing and Textiles Research Journal, 35(1), 1-16.

Chowdhury, J. \& J. Reardon \& R. Srivastava (1998), “Alternative modes of measuring store image: An empirical assessment of structured versus unstructured measures", Journal of Marketing Theory and Practice, 6(2), 72-86.

Chun, H.H. \& C.W. Park \& A.B. Eisingerich \& D.J. MacInnis (2015), "Strategic benefits of low fit brand extensions: When and why?", Journal of Consumer Psychology, 25(4), 577-595.

Collins-Dodd, C. \& T. Lindley (2003), "Store brands and retail differentiation: The influence of store image and store brand attitude on store own brand perceptions", Journal of Retailing and Consumer Services, 10(6), 345-352.

Cox, R. \& P. Brittain (2004), Retailing an Introduction (Fifth Edition), Edinburgh: Prentice-Hall.

Czellar, S. (2002), Consumer Attitude Towards Brand Extensions: An Integrative model and research propositions, <https://archive-ouverte.unige.ch/unige:5808>, 06.08.2020.

Çifci, S. \& A. Koçak (2012), "The impact of brand positivity on the relationship between corporate image and consumers attitudes toward brand extension in service businesses", Corporate Reputation Review, 15(2), 105-118.

de Ruyter, K. \& M. Wetzels (2000), "The role of corporate image and extension similarity in service brand extensions", Journal of Economic Psychology, 21(6), 639-659.

DelVecchio, D. \& D.C. Smith (2005), "Brand-extension price premiums: The effects of perceived fit and extension product category risk", Journal of the Academy of Marketing Science, 33(2), 184-196.

Dutzler, H. \& W. Kofler \& D.A. Nitschke \& M. Kittel (2016), Fashion's Way Forward An action plan for the hard-hit fashion industry,

<https://www.strategyand.pwc.com/gx/en/insights/fashions-way-forward.html>, 06.08.2020.

Dwivedi, A. \& B. Merrilees (2013), "Retail brand extensions: Unpacking the link between brand extension attitude and change in parent brand equity", Australasian Marketing Journal, $21,75-84$.

Ebster, C. \& M. Garaus (2015), Store Design and Visual Merchandising: Creating Store Space That Encourages Buying (2nd ed.), New York: Business Expert Press.

Echambadi, R. \& I. Arroniz \& W. Reinartz \& J. Lee (2006), "Empirical generalizations from brand extension research: How sure are we?", International Journal of Research in Marketing, 23(3), 253-261.

Fornell, C. \& D.F. Larcker (1981), "Evaluating Structural Equation Models with Unobservable Variables and Measurement Error", Journal of Marketing Research, 18(1), 39-50.

Franzoi, S.L. (2009), Social Psychology (5th ed.), New York: McGraw-Hill. 
Garvin, D.A. (1984), "Product quality: An important strategic weapon”, Business Horizons, 27(3), 40-43.

Gawronski, B. \& F. Strack (2004), "On the propositional nature of cognitive consistency: Dissonance changes explicit, but not implicit attitudes", Journal of Experimental Social Psychology, 40(4), 535-542.

Gültekin, B. \& L. Özer (2012), "Store Image's Influence on Perceived Quality of Store Brands and Store Brand Purchasing Behavior", Mediterranean Journal of Social Sciences, 3(6), 189195.

Gürhan-Canli, Z. \& G. Sarıal-Abi \& C. Hayran (2018), "Consumers and Brands Across the Globe: Research Synthesis and New Directions”, Journal of International Marketing, 26(1), 96117.

Hair, J.F. \& W.C. Black \& B.J. Babin \& R.E. Anderson (2014), Multivariate Data Analysis, Essex: Pearson Education Limited.

Hayes, A.F. \& N.J. Rockwood (2017), "Regression-based statistical mediation and moderation analysis in clinical research: Observations, recommendations, and implementation", Behavior Research and Therapy, 98, 39-57.

Howland, D. (2017), Target unveils \$7B plan to overhaul stores, digital operations, <https://www.retaildive.com/news/target-unveils-7b-plan-to-overhaul-storesdigitaloperations/437139/>, 06.08.2020.

Hwang, J. \& J.-E. Chung (2019), "What drives consumers to certain retailers for organic food purchase: The role of fit for consumers' retail store preference", Journal of Retailing and Consumer Services, 47, 293-306.

Jacoby, J. \& J.C. Olson \& R.A. Haddock (1971), "Price, Brand Name, and Product Composition Characteristics as Determinants of Perceived Quality", Journal of Applied Psychology, 55(6), 570-579.

Jordan, D. (2017), Dentsu Aegis Network, <http://www.dentsuaegisnetwork.com/media/dentsuaegisnetworknewsdetaila/2017/2017 _06_15?Global-ad-spend-to-hit-5634-billion-in-2017-with-digital-driving-growth>, 06.08.2020.

Keller, K.L. \& D.A. Aaker (1992), "The effects of sequential introduction of brand extensions", Journal of Marketing Research, 29(1), 35-50.

Kim, H. \& D.R. John (2008), "Consumer response to brand extensions: Construal level as a moderator of the importance of perceived fit", Journal of Consumer Psychology, 18, 116-126.

Kim, J. \& H.J. Yoon (2013), “Association ambiguity in brand extension”, Journal of Advertising, 42(4), 358-370.

Kline, R.B. (2011), Principles and practice of structural equation modelling, New York: The Guilford Press.

Klink, R.R. \& D.C. Smith (2001), "Threats to the External Validity of Brand Extension Research", Journal of Marketing Research, XXXVIII(August), 326-335.

Laforet, S. (2007), "British grocers' brand extension in financial services", Journal of Product \& Brand Management, 16(2), 82-97.

Lei, J. \& R. Pruppers \& H. Ouwersloot \& J. Lemmink (2004), "Service Intensiveness and Brand Extension Evaluations”, Journal of Service Research, 6(3), 243-255. 
Liljander, V. \& P. Polsa \& A. van Riel (2009), "Modelling consumer responses to an apparel store brand: Store image as a risk reducer", Journal of Retailing and Consumer Services, 16(4), 281-290.

Loken, B. \& D.R. John (1993), "Diluting Brand Beliefs: When Do Brand Extensions Have a Negative Impact?", Journal of Marketing, 57(July), 71-84.

Madellia (2018), The Customer Experience Tipping Point An Ipsos and Madellia study: U.S., U.K., Germany, and France, <Madellia:https://go.medallia.com/rs/669-VLQ276/images/Medallia_Ipsos_The_Customer_Experience_Tipping_Point.pdf>, 06.08.2020.

Martinelli, E. \& L. Sparks (2003), "Food retailers and financial services in the UK: A co-opetitive perspective", British Food Journal, 105(9), 577-590.

Maynard, M. (2018), “McDonald's is Spending \$6 Billion to Play Catch-Up”, Forbes, <https://www.forbes.com/sites/michelinemaynard/2018/08/15/mcdonalds-6-billionoverhaul-swipes-familiar-ideas-from-fast-casual-restaurants/\#3e6e01ce6e25", 06.08.2020.

Midi, H. \& S.K. Sarkar \& S. Rana (2010), "Collinearity diagnostics of binary logistic regression model”, Journal of Interdisciplinary Mathematics, 13(3), 253-267.

Milberg, S.J. \& R.C. Goodstein \& F. Sinn \& A. Cuneo \& L.D. Epstein (2013), “Call back the jury: Reinvestigating the effects of fit and parent brand quality in determining brand extension success", Journal of Marketing Management, 29(3-4), 374-390.

Monga, A.B. \& D.R. John (2010), "What Makes Brands Elastic? The Influence of Brand Concept and Styles of Thinking on Brand Extension Evaluation", Journal of Marketing, 74, 8092.

Park, C.W. \& S. Milberg \& R. Lawson (1991), "Evaluation of Brand Extensions: The Role of Product Feature Similarity and Brand Concept Consistency", Journal of Consumer Research, 18(2), 185-193.

Podsakoff, P.M. \& S.B. MacKenzie \& J.-Y. Lee \& N.P. Podsakoff (2003), "Common method biases in behavioral research: a critical review of the literature and recommended remedies", Journal of Applied Psychology, 88(5), 879-903.

PricewaterhouseCoopers (2016), Dönüşürken Büyüyen Türkiye Perakende Sektörü, <https://www.pwc.com.tr/tr/publications/industrial/retail-consumer/pdf/donusurkenbuyuyen-turkiye-perakende-sektoru-raporu.pdf>, 06.08.2020.

Ramanathan, J. \& S.K. Velayudhan (2015), “Consumer evaluation of brand extensions: Comparing goods to goods brand extensions with goods to services", Journal of Brand Management, 22(9), 778-801.

Rao, A.R. \& K.B. Monroe (1988), "The moderating effect of prior knowledge on cue utilization in product evaluations", Journal of Consumer Research, 15(September), 253-264.

Rao, A.R. \& K.B. Monroe (1989), “The effect of price, brand name, and store name on buyers' perceptions of product quality: An integrative review", Journal of Marketing Research, XXVI(August), 351-357.

Richardson, P.S. \& A.S. Dick \& A.K. Jain (1994), "Extrinsic and Intrinsic of Store Perceptions Cue Effects on Brand Quality", Journal of Marketing, 58(4), 28-36.

Rockwood, N.J. (2017), "Advancing the Formulation and Testing of Multilevel Mediation and Moderated Mediation Models", Master's Thesis, Graduate School of The Ohio State University, Ohio, United States. 
Salinas, M.E. \& J.M.P. Pérez (2009), “Modeling the brand extensions' influence on brand image”, Journal of Business Research, 62(1), 50-60.

Shao, J. \& J. Zhang \& K. Chen (2015), "Research on Brand Extension Feedback Effects Based on Customer Equity", South African Journal of Business Managment, 46(1), 97-105.

Sichtmann, C. \& A. Diamantopoulos (2013), "The impact of perceived brand globalness, brand origin image, and brand origin-extension fit on brand extension success", Journal of the Academy of Marketing Science, 41(5), 567-585.

Stein, A. \& B. Ramaseshan (2016), "Towards the identification of customer experience touch point elements", Journal of Retailing and Consumer Services, 30, 8-19.

$\mathrm{Su}$, J. (2016), "Examining the relationships among the brand equity dimensions", Asia Pacific Journal of Marketing and Logistics, 28(3), 464-480.

Sunde, L. \& R.J. Brodie (1993), “Consumer evaluations of brand extensions: Further empirical results", International Journal of Research in Marketing, 10(1), 47-53.

Tabanchnick, B.G. \& L.S. Fidell (2013), Using Multivariate Statistics (Sixth Edition), Boston: Pearson Education.

Taylor, V.A. \& W.O. Bearden (2002), "The Effects of Price on Brand Extension Evaluations: The Moderating Role of Extension Similarity", Journal of the Academy of Marketing Science, 30(2), 131-140.

Terres, M.S. \& M.M. Herter \& D.C. Pinto \& J.A. Mazzon (2020), "The power of sophistication: How service design cues help inservice failures", Journal of Consumer Behavior, 72(5), $1-14$.

Thorndike, E.L. (1920), “A constant error in psychological ratings”, Journal of Applied Psychology, 4(1), 25-29.

van Riel, A.C.R. \& J. Lemmink \& H. Ouwersloot (2001), "Consumer evaluations of service brand extensions", Journal of Service Research, 3(3), 220-23.

Verhoef, P.C. \& K.N. Lemon \& A. Parasuraman \& A. Roggeveen \& M. Tsiros \& L.A. Schlesinger (2009), "Customer Experience Creation: Determinants, Dynamics and Management Strategies", Journal of Retailing, 85(1), 31-41.

Vololato, N.L. \& H.R. Unnava (2006), "Spillover of Negative Information on Brand Alliances", Journal of Consumer Psychology, 16(2), 196-202.

Völckner, F. \& H. Sattler \& T. Hennig-Thurau \& C.M. Ringle (2010), "The Role of Parent Brand Quality for Service Brand Extension Success", Journal of Service Research, 13(4), 379396.

Völckner, F. \& H. Sattler (2006), "Drivers of Brand Extension Success”, Journal of Marketing, 70(2), 18-34.

Wood, Z. (2012), “Tesco's UK profits fall for first time in two decades”, The Guardian, <https://www.theguardian.com/business/2012/apr/18/tesco-uk-profits-fall-makeover>, 06.08.2020.

Yang, S. \& Y. Lu \& S. Gupta (2013), “An empirical investigation of mobile services’ cross-category promotions", International Journal of Mobile Communications, 11(6), 580-596. 